\title{
An odyssey through chronic pelvic pain in women
}

\author{
Ibrahim I Bolaji* and Ka yan Shirley SZE \\ Department of Obstetrics and Gynaecology, Hull York Medical School Diana, Princess of Wales Hospital, NLaG NHS Foundation Trust, UK
}

\begin{abstract}
The five common conditions encountered in patients with chronic pelvic pain (CPP) consist of endometriosis, interstitial cystitis, pelvic floor dysfunction, irritable bowel syndrome and pudendal nerve entrapment. The most unrecognised cause of CPP is the latter which affects only $4 \%$ of patients.

A thorough work up of patient's pain is necessary prior to subjecting patients to any intervention including surgery as over $40 \%$ of gynaecological laparoscopies are performed for long standing pelvic pain. CPP is of multi-source origin which makes it difficult in formulating a plan of care for patients with this condition. If one source of the pain is detected, it is important to rule out other conditions that may also be contributing.
\end{abstract}

All practitioners treating patients with CPP have to be knowledgeable about all of the potential causes of pelvic pain and addressing only the commonest cause like endometriosis is not adequate.

\section{Sources and Selection Criteria}

We performed a Medline and Embase search using the MeSH terms, evidenced based guidelines and published consensus statements from 1992 to date, limited to publications in English and to chronic pelvic pain in women. Our search strategy was very broad using a combination of $\mathrm{MeSH}$, text-words and appropriate word variants of causes of chronic pelvic pain including chronic pelvic pain syndrome, endometriosis, bladder pain syndrome, interstitial cystitis, pelvic floor dysfunction, irritable bowel syndrome and pudendal nerve entrapment or pudendal neuralgia.

\section{What is chronic pelvic pain?}

Pain is defined by the International Association for the Study of Pain as 'an unpleasant sensory and emotional experience associated with actual or potential tissue damage [1]. Understanding the impact of pain has to acknowledge both the stimulation of the sensory receptors by a harmful stimuli and other factors acting centrally and contributing to pain perception. Chronic pelvic pain (CPP) is regarded as a symptom and not a diagnosis and its definition encompasses three parameters of location, severity and duration. It is most commonly defined as pain located in the lower abdominal or pelvic cavity or buttocks which can be continuous or intermittent, cyclical or non-cyclical in nature. It imposes functional limitation in activities of daily living (ADLs), leading to poorer quality of life [2] (severity). The pain must have been persistent for at least 6 months [3] (duration).

The pelvis is a complex region of the body and its geography and complicated neuroanatomy makes diagnosis of pain in the region extremely challenging. There is a very heavy economic and social implication for patients living with chronic pelvic pain. Hence, it is of paramount importance that accurate diagnosis and effective management of this condition be implemented very early in the presentation. CPP is of multi-source origin which makes it difficult in formulating a plan of care for patients with this condition. If one source of the pain is detected, it is important to rule out other conditions that may also be contributing. For example, Howard [4] estimated that approximately $65 \%$ of women with endometriosis have coexistence of interstitial cystitis which may account for some patients failing to have a remission of their symptoms as only one condition is being addressed.

\section{How common is this condition?}

The estimated worldwide prevalence of CPP ranges from $2.1-24 \%$ [1]. It is more prevalent in females and its prevalence in women of reproductive age in the USA and the UK has been reported as $14.7 \%$ and $24 \%$ respectively $[5,6]$. The direct costs of CPP has been estimated to be as high as $\$ 2.8$ billion [4,5]. In gynaecology, endometriosis is perceived by many to be the main source of CPP and it has been cited as being the cause of CPP in $30-87 \%$ of patients [7].

\section{What are the possible causes of chronic pelvic pain?}

The aetiology of CPP is multifactorial and incompletely understood and it can arise from pathologies involving various organ systems [8] (Figure 1). Pain disorders may coexist with CPP and intensify the overall pain symptoms via mechanisms of cross-organ sensitisation, leading to viscero-visceral or viscerosomatic hyperalgesia [9]. The complex innervation of the pelvis further complicates the diagnosis of pelvic pain [1].

Pain can generally be classified into visceral, somatic or neuropathic. Visceral pain originates from internal organs and is transmitted through sympathetic fibers of the autonomic nervous system. It is thus poorly localised, dull and aching in nature and associated with autonomic dysfunction (e.g. nausea, vomiting, sweating) [10].

${ }^{\star}$ Correspondence to: Ibrahim I Bolaji, Department of Obstetrics and Gynaecology, Hull York Medical School Diana, Princess of Wales Hospital, NLaG NHS Foundation Trust, Scartho Road, Grimsby DN33 2BA, UK, Tel: 01472-874-111; Fax: 01-472-875-452; E-mail: iibolaji@yahoo.com

Key words: Chronic pelvic syndrome, endometriosis, bladder pain syndrome, interstitial cystitis, pelvic floor dysfunction, irritable bowel syndrome and pudendal nerve entrapment

Received: August 23, 2018; Accepted: September 20, 2018; Published: September 24, 2018 


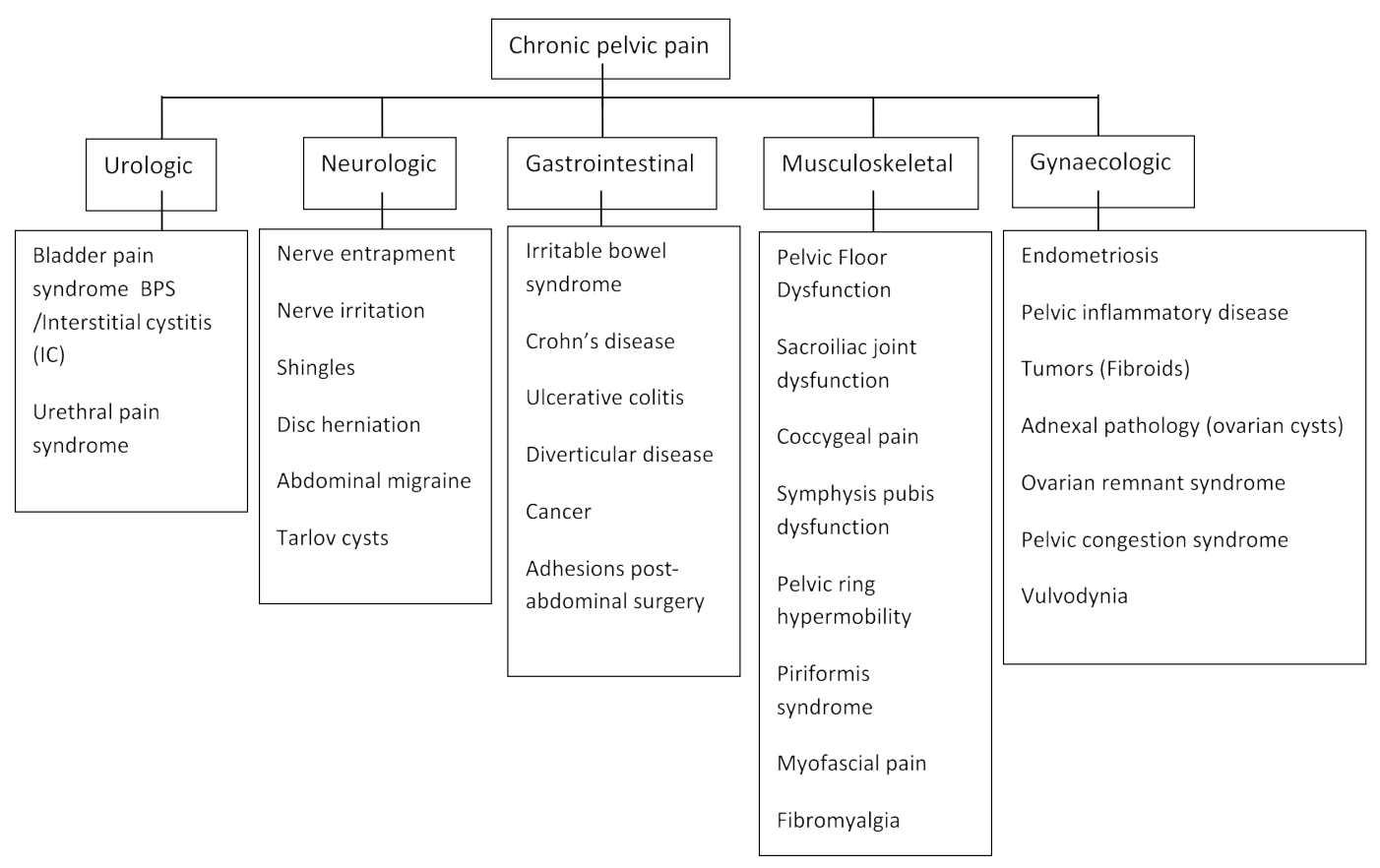

Figure 1. Aetiology of chronic pelvic pain

On the other hand, somatic pain originates from muscles, skin, bones and joints and is transmitted along somatic sensory afferents. Hence, this pain is well localised and sharp or burning in nature $[2,11$.

Pain as a result of changes in the nerve itself is referred to as 'neuropathic pain'. This pain is characteristically, but not exclusively burning, aching or shooting in nature and presents as hyperaesthesia, dysaesthesias and allodynia [2]. It arises as a result of an injury to the peripheral or central somatosensory nervous system. CPP is thought to originate from a disease state that damages a particular organ giving rise to either somatic or visceral pain, which then develops into neuropathic pain over time.

In cases where no precise pathology can be identified, CPP is thought to be due to abnormal pain perception in the central nervous system (CNS) in the absence of acute injury [12]. Janicki [13] proposed that CPP is a form of complex regional pain syndrome (CRPS), resulting in hypersensitization of the CNS and hence decreased pain thresholds and augmented normal pain intensities [15]; such that normally nonnoxious stimuli (e.g. the sensation of a full bladder) would be perceived as painful.

\section{What is the approach to assessment and making a clinical diagnosis?}

The triad of thorough history, clinical examination and utilisation of laboratory and imaging studies are essential to arrive at an accurate diagnosis. The signs and symptoms of CPP are very variable in terms of location and intensity. Initial assessment of women with CPP is the most important and this must be performed thoroughly and meticulously without haste. Patients must be allowed to narrate their story with attentiveness so as to explore their ideas about the cause of pain and use the opportunity to reinforce some of their thoughts and discard misconception regarding the pain. McGowan et al. [15] and Price et al. [16] found that patients presenting with CPP want their history to be heard and validated and they want to receive individualised care to improve their understanding and management of their pain.
The initial detail history should capture information about the pattern of the pain, associated problems including urinary, bowel or psychological problems and the effect on posture and movement. One acronym that the authors found useful for assessment of chronic pelvic pain and used by many healthcare professionals is SOCRATES (Table 1).

In history, it is critical to ask not only about pain but also to explore other systems including urologic, gastrointestinal, musculo-skeletal and reproductive systems. Although there are many contributory factors but the problem of CPP must be considered as a whole by the physician and their clients. A pain/menstrual chart may be helpful in tracking symptoms or activities associated with this pain. Where pain is cyclical in the absence of any other finding, a therapeutic trial of down regulation may be more helpful than a diagnostic laparoscopy.

Nickel et al. [17] championed the use of UPOINT (urinary, psychosocial, organ-specific, infection, neurologic/systemic and muscle tenderness) [18] system (Table 2) to structurally classify and improve management of patients with CPP. This enables the appropriate diagnostic investigation to be carried out to identify the underlying cause of pain, so that more effective treatment can be recommended by targeting on the particular aetiology. The UPOINT approach appears to be a valid initial assessment of a patient's pain complaints $[19,20]$ and more commonly used by the urologists. The full diagnostic criteria of different causes of CPP are explored in the differential diagnosis.

Clinically, palpation of the bladder and pelvic floor muscles are very important and often ignored due to lack of training. Bladder pain may be elicited in BPS/IC and there are two highly predictive physical examination for pelvic floor dysfunction [21]. These are the Pelvic floor muscle palpation (PMP) and the forced Flexion, Abduction, and External Rotation (fFAER) tests. They may help to identify those that have musculoskeletal disorders contributing to chronic pelvic pain and who would benefit from referral to a physiotherapist.

Endometriosis-related lesions may be palpated during early part of menstrual flow as the implants are most likely large and tender at this 


\begin{tabular}{|c|c|c|}
\hline $\mathbf{S}$ & Site & $\begin{array}{l}\text { Where is the pain? Chest, abdomen, head, pelvis, etc. Is there } \\
\text { a pattern of involvement? }\end{array}$ \\
\hline $\mathbf{O}$ & Onset & $\begin{array}{l}\text { When did it start? How did it start? What started it? Was it } \\
\text { a sudden onset or more gradual? Has there been any change } \\
\text { over time? }\end{array}$ \\
\hline $\mathbf{C}$ & Character & $\begin{array}{l}\text { What does pain feel like now? } \\
\text { Type of pain - burning, shooting, stabbing, crushing, dull } \\
\text { Pattern of pain - colicky, constant }\end{array}$ \\
\hline $\mathbf{R}$ & Radiation & Where does it move to? Into back, arm, down a leg, etc. \\
\hline $\mathbf{A}$ & Associations & $\begin{array}{l}\text { Are any other signs or symptoms associated with pain? E.g. is } \\
\text { there any neurological deficit (e.g. numbness where the pain } \\
\text { is felt?) Does it cause nausea, light-headedness, inability to } \\
\text { lie flat, etc }\end{array}$ \\
\hline $\mathbf{T}$ & Timing & $\begin{array}{l}\text { Time course - does the pain follow any pattern? Is the pain } \\
\text { worse at any time of the day? Is the pain associated with any } \\
\text { particular activities, e.g. movement, urination, eating, passing } \\
\text { stool, coughing, is It constant / intermittent, how long does it } \\
\text { last when it's there? }\end{array}$ \\
\hline $\mathbf{E}$ & $\begin{array}{l}\text { Exacerbating / } \\
\text { relieving factors }\end{array}$ & $\begin{array}{l}\text { What makes it better or worse? does anything change the } \\
\text { pain? }\end{array}$ \\
\hline $\mathbf{S}$ & Severity & $\begin{array}{l}\text { How bad is it now? } \\
\text { - Pain intensity: none, mild, moderate or severe; rank on a } \\
\text { scale of } 1-10 \text { scale } \\
\text { - Any interference with sleep or usual activities } \\
\text { - Pain relief: none, slight, moderate, good or complete }\end{array}$ \\
\hline
\end{tabular}

Table 2. UPOINT system for Clinical Phenotyping of Chronic Pelvic Pain: minimum investigations recommended [19]

\begin{tabular}{|l|l|}
\hline Urinary & A post-void residual measured by ultrasound \\
\hline Psychosocial & $\begin{array}{l}\text { Ask about clinical depression and catastrophizing } \\
\text { (helplessness, hopelessness) }\end{array}$ \\
\hline Organ specific & Pain improvement with bladder emptying and tenderness \\
\hline Infection & Culture for myocoplasma and ureasplasma, urine culture \\
\hline Neurologic/Systemic & $\begin{array}{l}\text { Ask about pain outside the pelvic and diagnosis of other pain } \\
\text { syndromes }\end{array}$ \\
\hline Tenderness & $\begin{array}{l}\text { Palpate the abdominal and pelvic skeletal muscles (via rectum } \\
\text { or vagina) and check for spasm and trigger points }\end{array}$ \\
\hline Additional tests & Female Urologic Pelvic Pain Index \\
\hline
\end{tabular}

phase of the menstrual cycle. A common physical finding is cul-de-sac tenderness, with multiple tender nodules palpated along the cul-de-sac or uterosacral ligaments. Adnexal masses or adhesions are palpated bimanually, while deep infiltrated lesions involving the rectovaginal septum are palpated rectovaginally.

Investigations vary according to history and examination findings as shown in Table 3. In gynaecology, diagnostic laparoscopy appears to be the most frequent and the best investigation for CPP $[22,23]$. The laparoscopy must be comprehensive exploring the upper abdomen, chest as well as the pelvic cavities (Figure 2). However, it is important to bear in mind that a negative laparoscopy, (present is up to $90 \%$ of women with CPP [24] is not synonymous with no diagnosis or no disease). Laparoscopy is only one of the many possible methods of evaluation of CPP. It has its limitations and pitfalls. More discriminative use of laparoscopy based on the patient's history, clinical examination, laboratory and imaging findings might decrease the rate of negative laparoscopies from $39-40 \%$ [23].

Frequently, the diagnosis of CPP is assigned to a painful condition dependent on the initial specialist who evaluated the patient, i.e. gynaecologists assign gynaecologic diagnoses, whereas urologists assign urologic diagnoses. It is prudent for clinicians from all specialties to assess the multiple aetiologies that are possible in causing CPP.

\section{What are the common causes of chronic pelvic pain?}

In gynaecological population, the five prevalent conditions encountered in patients with chronic pelvic pain include endometriosis, bladder pain syndrome/interstitial cystitis (BPS/IC), irritable bowel syndrome (IBS), pelvic floor dysfunction (PFD) and pudendal nerve entrapment (PNE) (Table 4). The most unrecognised cause of CPP is the PNE which affects only $4 \%$ of patients with chronic pelvic pain. Pelvic congestion syndrome refers to a condition in which characteristic symptoms of shifting location of pain, deep dyspareunia, post-coital pain, and exacerbation of pain after prolonged standing are associated with radiological findings of pelvic varicosities (dilated uterine and ovarian veins) that display reduced blood flow [25]. The existence of pelvic venous congestion as a cause of chronic pelvic pain remains controversial. A recent systematic review of diagnosis and management of this condition found no valid diagnostic tests, although ovarian suppression was effective in treating pelvic pain symptoms. Pelvic inflammatory disease (PID) is a common cause of CPP in settings with a high prevalence of sexually transmitted disease. However, the underlying reason that PID often leads to CPP has not been clearly established. In one study of 780 predominantly black urban women with recently diagnosed PID, those most likely to develop CPP were smokers, women with a history of two or more episodes of PID, and women with a low composite mental health score on standardized tests [26].

\section{Endometriosis}

Endometriosis refers to ectopic implantation and growth of endometrial mucosa, glands and stroma, commonly involving the ovaries, uterosacral ligaments, Pouch of Douglas and uterovescial peritoneum [27,28]. Since these extrauterine implants are under cyclic influence of ovarian hormones, they grow and break down with each menstrual cycle. The symptoms of endometriosis vary in their presentation and severity; however, the commonest symptom is premenstrual pelvic pain and dyspareunia [29-61]. The pain usually begins one or two days before expected menstruation, and it may be unilateral or bilateral, and lasts until the end of menses. However, some women may experience a constant, debilitating pain that interferes with functional activities of daily living. Curiously, the severity of pain does not correlate well with severity of the condition and, therefore, severe disease may go undiagnosed [30].

This pain can be attributable to several factors, namely inflammation secondary to cyclic slough of endometrial glands; release of neurokinins and adhesions causing pressure and traction on surrounding tissues [61]. However, it is important to note that endometriotic pain has little correlation with the location and extent of disease, in other words, some patients with endometriosis may be completely asymptomatic $[60,61]$. If the bladder is involved, patients may also complain of dysuria, hematuria and urinary frequency [31].

The pathophysiology of endometriosis remains unknown. Although many theories have been proposed, the most accepted theories include retrograde menstruation (Sampson's theory), coelomic metaplasia, vascular and lymphatic spread and altered immunosurveillance.

Endometriosis is clinically graded into four stages of advancement according to the American Society of Reproductive Medicine classification (ASRM) [32] to assist with diagnosis, prognosis, treatment, subsequent progress and communication among medical professionals. They are Stage I (minimal), Stage II (mild), Stage III (moderate) and Stage IV (severe). Staging is based on the extent 
Table 3. Summary of findings in history (pain characteristics, associated symptoms), examination, investigation and treatment for five common aetiologies of chronic pelvic pain

\begin{tabular}{|c|c|c|c|c|c|}
\hline & BPS/IC & IBS & PFD & PNE & Endometriosis \\
\hline Pain & $\begin{array}{l}\text { Pain worsens as bladder fills and } \\
\text { improves after voiding }\end{array}$ & \multirow{2}{*}{$\begin{array}{l}\text { Rome criteria: } \\
\text {-Continuous/recurrent abdominal } \\
\text { pain, relieved with defaecation/ } \\
\text { associated with change in frequency/ } \\
\text { consistency of stool } \\
\text {-+/- disturbed defaecation ( } 2 \text { or } \\
\text { more of: altered stool frequency/ } \\
\text { consistency/ passage of stools } \\
\text { (straining/ urgency/tenesmus)/ } \\
\text { passage of mucus } \\
\text {-Usually with bloating } \\
\text { Exclude red flag symptoms: } \\
\text { (significant weight loss, nocturnal } \\
\text { symptoms, bloody diarrhoea, family } \\
\text { history of colon cancer, new onset of } \\
\text { symptoms in patients }>50 \text { years) } \\
\text { More commonly suffers from } \\
\text { concomitant chronic fatigue } \\
\text { syndrome, fibromyalgia, depression, } \\
\text { anxiety }\end{array}$} & $\begin{array}{l}\text { Well-localised, aching } \\
\text { and deep in nature, } \\
\text { focal point tenderness } \\
\text { Associated with obesity, } \\
\text { menopause, pregnancy, } \\
\text { childbirth and inherited } \\
\text { collagen deficiency }\end{array}$ & $\begin{array}{l}\text { Pain is positional } \\
\text { (worsened by sitting, } \\
\text { relieved by standing, } \\
\text { absent when recumbent } \\
\text { More common in } \\
\text { competitive cyclists, after } \\
\text { pregnancy, trauma, surgery } \\
\text { due to scarring }\end{array}$ & $\begin{array}{l}\text { Perimenstrual lower } \\
\text { abdominal pain }\end{array}$ \\
\hline $\begin{array}{l}\text { Associated } \\
\text { symptoms }\end{array}$ & $\begin{array}{l}\text { Urgency, hesitancy, frequency, } \\
\text { dyspaurenia (Pelvic Pain and Urgency/ } \\
\text { Frequency (PUF) patient symptom } \\
\text { scale to act as a screening test for IC) }\end{array}$ & & $\begin{array}{l}\text { Pseudo-weakness of the } \\
\text { involved muscles and } \\
\text { reduced range of motion }\end{array}$ & $\begin{array}{l}\text { Genital numbness, urinary/ } \\
\text { faecal incontinence }\end{array}$ & $\begin{array}{l}\text { dyspareunia } \\
\text { dysuria, haematuria, urinary } \\
\text { frequency (if bladder } \\
\text { involvement) }\end{array}$ \\
\hline Signs & Tenderness at bladder base & Normal examination & $\begin{array}{l}\text { Levator muscle spasm, } \\
\text { myofascial pain elicited } \\
\text { by pelvic floor muscle } \\
\text { palpation (PMP) and the } \\
\text { forced flexion, abduction } \\
\text { and external rotation test } \\
\text { (fFAER) }\end{array}$ & $\begin{array}{l}\text { Palpation of the ischial } \\
\text { spine may produce pain }\end{array}$ & $\begin{array}{l}\text { tender retroverted uterus, } \\
\text { tender nodules and masses } \\
\text { in pelvis, implants in } \\
\text { uterosacral ligaments }\end{array}$ \\
\hline Investigations & $\begin{array}{l}24 \mathrm{hr} \text { voiding diary, To detect infection/ } \\
\text { haematuria: Urinalysis, urine culture } \\
\text { To exclude bladder cancer or carcinoma } \\
\text { in situ: urine cytology } \\
\text { To establish diagnosis: } \\
\text { Cystoscopy with hydrodistention of } \\
\text { bladder } \\
\text { Intravesical anaesthetic challenge }\end{array}$ & $\begin{array}{l}\text { Diagnosis of exclusion, } \\
\text { (investigations to rule out organic } \\
\text { causes e.g. lactose intolerance } \\
\text { (Hydrogen breath test), coeliac } \\
\text { disease (coeliac serology), small } \\
\text { bowel bacterial overgrowth (stool } \\
\text { microscopy+ culture), colorectal } \\
\text { cancer: colonoscopy + biopsy for } \\
\text { patients over } 50 \text { years or }<50 \text { with } \\
\text { red flag symptoms) }\end{array}$ & -- & $\begin{array}{l}\text { EMG: to measure } \\
\text { motor latency along the } \\
\text { pudendal nerve (a greater } \\
\text { than normal conduction } \\
\text { delay indicates nerve } \\
\text { entrapment) } \\
\text { MR neurography: } \\
\text { asymmetrical swelling } \\
\text { and hyperintensity in } \\
\text { the affected pudendal } \\
\text { neurovascular bundle }\end{array}$ & $\begin{array}{l}\text { Laparoscopy +biopsy for } \\
\text { visualisation of lesions + } \\
\text { histological confirmation } \\
\text { (false +: endosalpingiosis, } \\
\text { malignancies, carbon } \\
\text { deposits from previous } \\
\text { ablations) }\end{array}$ \\
\hline Treatment & Table 4 & $\begin{array}{l}\text { Dietary modification (high-fibre diet, } \\
\text { increase fluid intake) } \\
\text { Psychotherapy (CBT, stress } \\
\text { management) } \\
\text { Antispasmodics } \\
\text { Tricyclics or SSRI }\end{array}$ & $\begin{array}{l}\text { Physiotherapy e.g. } \\
\text { Pelvic floor exercise, } \\
\text { muscle relaxants, } \\
\text { electrical stimulation to } \\
\text { increase muscle tone, } \\
\text { biofeedback }\end{array}$ & $\begin{array}{l}\text { Behavioral modification, } \\
\text { physical therapy } \\
\text { (stretching exercises), } \\
\text { analgesics, medication } \\
\text { for neuropathic pain } \\
\text { (gabapentin, amitriptyline), } \\
\text { pudendal nerve block, } \\
\text { surgical decompression, } \\
\text { pulsed radiofrequency }\end{array}$ & $\begin{array}{l}\text { Medications: Analgesics: } \\
\text { NSAID } \\
\text { HRT (COCP), progestins } \\
\text { Danazol, } \\
\text { GnRH } \\
\text { Surgery: laparoscopy + } \\
\text { ablation of endometriosis or } \\
\text { hysterectomy with bilateral } \\
\text { salpingo-oorphorectmy }\end{array}$ \\
\hline
\end{tabular}

CBT: Cognitive behavioural therapy is a talking therapy that can help patient to manage their problems by changing the way they think and behave, COCP: combined oral contraceptive pills, EMG: electromyography, GnRH: gonadotropin-releasing agonist, IBS: irritable bowel syndrome, IC: interstitial cystitis, MPS: Myofascial pain syndrome, NSAID: nonsteroidal antiinflammatory agents, PFD: Pelvic floor dysfunction, PNE: pudendal nerve entrapment, PUF: Pelvic Pain and Urinary/Frequency patient symptom scale.
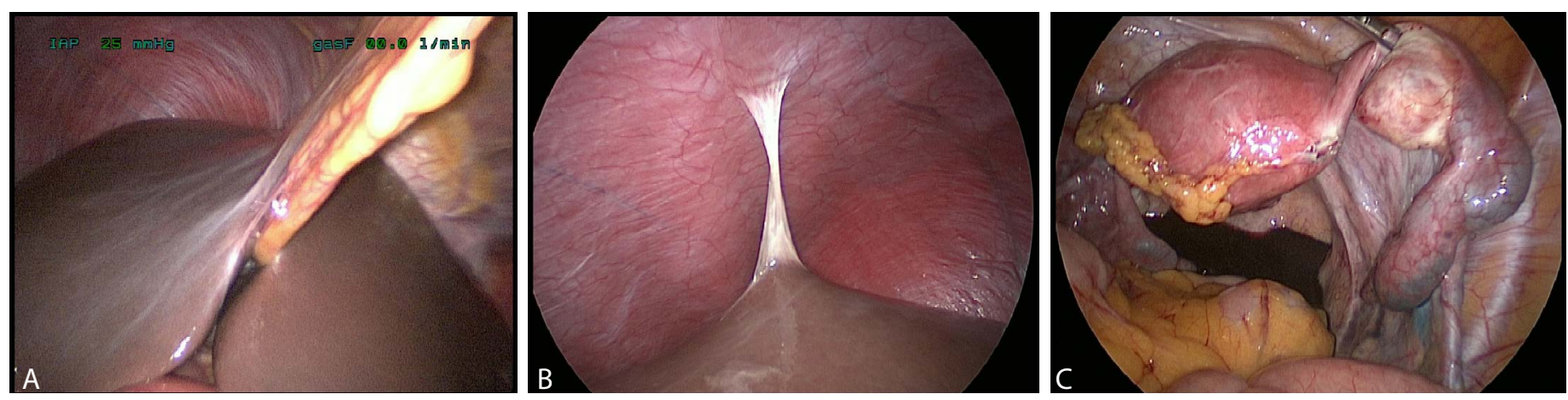

Figure 2A. Normal looking perihepatic space. 2B) Type 1 Fitz-Hugh Curtis syndrome. 2C) Chronic PID with hydrosalpinx. 
Table 4. The evil quintuplet

Endometriosis

Irritable Bowel Syndrome

Bladder Pain Syndrome/Interstitial Cystitis (BPS/IC)

Pelvic Floor Dysfunction

Pudendal Nerve Entrapment

of the spread of lesions, density of pelvic adhesions, involvement of pelvic organs and degree of fallopian tube occlusion. It's important to remember that the stage of endometriosis is not reflective of degree of pain, risk of infertility or predictive of the patient's ability to conceive after therapy.

On examination, tender nodules and masses in the pelvis, a tender, retroverted, fixed uterus or implants in the POD or uterosacral ligaments are suggestive of endometriosis. The gold standard diagnostic investigation for endometriosis is laparoscopy with confirmation by biopsy $[60,61]$. However, false positives can occur with malignancies, endosalpingiosis, carbon deposits from previous ablations and even with normal peritoneum. Walter et al. [33] investigated the accuracy of solely using laparoscopic visualization in diagnosing endometriosis and found that only 67 out of 138 (49\%) sites visually positive were also histologically positive.

Management options include medical, surgical or a combination of both (Table 3), depending on the patient's age and their desire for fertility augmentation and pain relief and also the stage of disease. Mild, premenstrual endometriotic pain responds well to non-steroidal anti-inflammatories (NSAIDs) [34]. Hormonal therapy suppresses oestrogen production and promotes atrophy of endometrial tissue implants. Low dose, continuous, monophasic combined oral contraceptives (COC) is the first-line hormonal therapy [67]. Progestins (e.g. medroxyprogesterone acetate, norethindrone acetate), gonadotropin-releasing ( $\mathrm{GnRH})$ agonists (e.g. goserelin, leuprolide) and danazol are alternative hormonal therapies [67]. GnRH agonists and COCs have been shown to be beneficial for patients with IBS, BPS/ IC and pain disorders associated with perimenstrual flare-ups [35]. Interestingly, a phase II randomised controlled trial in Brazil showed that oral therapy with melatonin $10 \mathrm{mg} / \mathrm{d}$ was more effective than placebo in improving daily pain, dysmenorrhea, dysuria, dyschezia and sleep in women with biopsy-proven endometriosis and CPP [36].

Surgery may be considered in older patients or those who suffers from moderate or severe endometriosis unresponsive to pharmacologic treatment. Conservative surgery eradicates visual signs of endometriosis and adhesions. Residual microscopic implants which cannot be surgically removed contribute to symptom recurrence and disease progression. For women with severe persistent endometriosis, more invasive surgeries may be considered e.g. hysterectomy with bilateral salpingo-oophorectomy. Patients who undergo a bilateral oophorectomy should be treated with hormone replacement therapy as the benefits outweigh the risk of endometriosis recurrence (ASRM).

The recurrence rate of endometriotic lesions after five years is $19 \%$ with laparoscopic removal of lesions and $10 \%$ with hysterectomy and bilateral oophorectomy, this is compared with $53.4 \%$ with medical treatment (ASRM). However, this doesn't reflect the recurrence rate of pain as many women have a recurrence of pelvic pain [37].

\section{Irritable bowel syndrome (IBS)}

IBS is the commonest bowel disorder, affecting over $10 \%$ of the population and it is 3 times more prevalent in women than men, mostly affecting women aged between 15 and 45. Although IBS is a chronic problem, it is however a benign disorder, and does not progress to, or increase the risk of any other disease. It has no known cure yet and its treatment remains symptomatic relief.

Although the underlying pathophysiology remains unclear, emerging literature suggests that IBS arises as a result of intestinal inflammation which emerges from hyper-responsiveness of the neuronal, immune and endocrine signalling pathways within the intestines, the peripheral and the central nervous system [38]. Consequently, the hypersensitive bowel muscles go into spasm, causing pain. Certain foods may trigger an attack. Stressful life events are reported by up to $60 \%$ of IBS patients, which can exacerbate symptoms.

The cardinal symptoms of IBS consist of a triad of abdominal pain, abdominal bloating and a change in bowel habit [39] and attempts to refine this clinical approach into guidelines have resulted in several diagnostic criteria being created including the Manning criteria and Rome I-III criteria. The Rome criteria, initially introduced in 1988 and subsequently modified twice to yield the Rome III criteria, have become the research-standard definition of constipation and IBS [40]. The Rome III criteria for the diagnosis of irritable bowel syndrome require that patients have had recurrent abdominal pain or discomfort at least 3 days per month over the last 3 months that is associated with 2 or more of the following: improvement with defecation, change in frequency of evacuations and variations in the form (appearance) of stool (criteria) [42]. The NICE guidelines however recommend assessment of IBS in patients with symptom lasting longer than six months [41].

The Roman criteria have proved useful for research purposes by ensuring homogeneity of patient populations, but their applicability in clinical practice is extremely limited and they are seldom used [42]. The diagnosis of IBS is usually made more often intuitively with remarkable reliability and safety.

IBS often exhibits the following subgroups: Constipation predominant IBS, which is more prevalent in females and is characterised by alternating hard $(>25 \%)$ and soft stools $(<25 \%)$; diarrhoea predominant IBS, which is more common in males and is characterised by alternating loose $(>25 \%)$ and hardened stools $(<25 \%)$ and IBS with mixed habits [39].

Most gynaecologists have difficulty recognising bowel symptoms and, therefore, do not establish a diagnosis of IBS [43-45]. The difficulty of the diagnosis is further increased by the fact that symptoms of IBS are based on subjective accounts of patients and lack organic explanations.

The treatment of first choice is usually a dietary modification by increasing fibre and fluid intake. Drug therapy is not usually recommended for the routine treatment of IBS. However, antispasmodics, tricyclics or selective serotonin reuptake inhibitors (SSRI) might be beneficial. Psychotherapy including cognitive behavioural therapy (CBT) and stress management might also be helpful in controlling symptoms (Table 3).

\section{Bladder pain syndrome}

Formally referred to as interstitial cystitis, the nomenclature for this condition has changed several times. There is currently no consensus regarding the nomenclature and sometimes both titles have been combined as BPS/IC. BPS is the most widely used term in the UK and Europe whilst BPS/IC is the preferred term by the American Association of Urologist (AUA). The prevalence in the female population in the United States ranged from 3-6\% [46]. 
BPS is defined as "an unpleasant sensation (pain, pressure, discomfort) perceived to be related to the urinary bladder" that is associated with urinary symptoms, in the absence of infection or other identifiable causes [47]. BPS/IC was defined by the International Continence Society in 2002 as suprapubic pain related to bladder filling after exclusion of a urinary tract infection, along with 1 or 2 of increased daytime frequency and or increased night time frequency [48]. The classic features include urinary urgency and frequency, nocturia, dyspareunia and pelvic or lower abdominal pain [49].

The European Society for the Study of Interstitial Cystitis (ESSIC) proposed the term BPS to be used in parallel with or instead of IC in accordance to the following criteria [50]: chronic pelvic pain lasting > 6 months, pressure or discomfort perceived to be related to the urinary bladder and accompanied by at least one other urinary symptom like urinary urgency or frequency.

The aetiology of BPS/IC is still undetermined but possible causes include infection, toxins, bladder wall defects, pelvic floor dysfunction and autoimmune disorders [51]. The most likely primary cause seems to be a defective urothelium or glycosaminoglycan (GAG) layer [52]. Clinical BPS/IC, according to Keay et al. [53] is initiated by exposure to noxious stimuli causing injury to the bladder or epithelium, commonly following an episode of bacterial cystitis, pelvic surgery, childbirth or urologic instrumentation. In contrast to the healthy population, normal uroepithelial repair in BPS/IC patients is retarded or prevented as a result of elevated anti-proliferative factor and diminished epithelial growth factors [54]. Over time, the GAG layer becomes defective and urinary metabolities e.g. potassium ions $(\mathrm{K}+)$ leak through the bladder wall into the submucosal space, triggering an inflammatory reaction marked by proliferation and activation of submucosal mast cells [55]. Penetration of urinary constituents into the bladder wall causes C-fiber activation, mast cell activation, and histamine release. The resulting smooth muscle contraction, neurogenic inflammation, and hypersensitivity translate into the urinary urgency and frequency and chronic pelvic pain that are characteristic symptoms of several chronic bladder conditions. Mast cell degranulation not only releases histamine and other inflammatory mediators, eliciting local tissue damage and vasoconstriction [56], but also stimulates neurogenic inflammation [57] by activating capsacin-sensitive nerve fibers and releasing neuropeptides such as substance $P$ which leads to further injury and fibrotic changes within the bladder. If left untreated, the bladder will shrink in size, compromising its functional capacity. Chronic inflammation fuels neural up-regulation and neural changes within the spinal cord which ultimately develops into neuropathic pain, manifesting as allodynia and hyperalgesia of the bladder and adjacent pelvic organs [58]. This up-regulation explains the reason for patients with chronic BPS/IC to have persistent vaginal or pelvic pain even after cystectomy.

Without a thorough investigation, BPS/IC can be easily misdiagnosed as vaginitis, vulvodynia or pelvic floor dysfunction in female patients. The diagnosis of BPS/IC can be confirmed via cystoscopy, with or without biopsy and hydrodistention. On cystoscopy, Hunter's ulcers may be present in $10 \%$ of patients [39]. Hydrodistention may reveal petechial haemorrhages (glomerulations) in symptomatic patients which are indicative of disease state [59]. Histological examination may show signs of neurogenic inflammation, evidenced by marked oedema and injury to nervous tissues and blood vessels in the muscularis layer [39].

There are a large number of therapies available to treat BPS/IC. The majority of patients respond well to a multidisciplinary approach consisting of dietary modification, behavioural modification and other medical interventions (Figure 3, Table 5).

\section{Pelvic floor dysfunction}

Pelvic floor dysfunction is a well-known musculoskeletal cause of CPP. It occurs when pelvic floor muscles are either too weak or too tight. The major contributing factors include obesity, menopause, pregnancy and childbirth. Some women are more likely to developing pelvic floor dysfunction as a result of an inherited collagen deficiency. Keane et al. [60] found that women with congenitally weak connective tissue and fascia are at risk of stress urinary incontinence and pelvic organ prolapse.

Pelvic floor muscle palpation (PMP) is a useful physical examination technique to determine whether CPP is of musculoskeletal origin. The test is considered to be positive if firm transvaginal digital palpation of the right and left pelvic floor muscles elicits pain [61]. The forced Flexion, Abduction and External Rotation test (fFAER) is considered to be positive when pain is elicited by flexion, abduction and external rotation of either leg from the supine position [49]. The presence of both findings correctly identifies patients with musculoskeletal disorders contributing to CPP in $85 \%$ of the time while the absence of both findings has $100 \%$ specificity [49]. Physiotherapy is typically beneficial in relieving symptoms of the musculoskeletal origin (Table 3).

\section{Pudendal nerve entrapment}

Pudendal nerve entrapment or pudendal neuralgia is a disabling form of genital pain resulting from inflammation, compression or entrapment of the pudendal nerve $(S 2,3,4)$, affecting $4 \%$ of patients presenting with CPP. It has been associated with childbirth, pelvic surgery, intense cycling, sacroiliac skeletal abnormalities or age-related changes. Post-menopausal women have especially high risks since pudendal neuralgia has been shown to be related to urogenital atrophy as a result of decreased oestrogen level and hence collagen support as women age [62].

Clinical features include pelvic pain with sitting which worsens throughout the day and decreases with standing or lying down. This condition is thus very common in current society since many people have office jobs and make frequent, long journeys [63]. Similar to other causes, pudendal neuralgia is also associated with sexual dysfunction and difficulty in urination and defaecation, consequently, the diagnosis is often difficult to manage with a reported delay ranging from 2 to 10 years [64]. There are 5 essential diagnostic criteria (Nantes criteria) [65] that are recommended for the diagnosis of pudendal neuropathy (Table 6).

There must be no symptoms of exclusion criteria. Patients with solely coccygeal, gluteal or hypogastric pain with imaging abnormalities that may explain the symptoms generally do not have pudendal neuralgia. The diagnosis should be confirmed with electrophysiological and imaging studies such as colour duplex scanning and magnetic resonance neurography. Electromyography with a greater than normal conduction delay may suggest pudendal nerve entrapment in Alcock's canal.

Pudendal neuralgia can be managed with either conservative or surgical approaches (Table 3). Conservative treatment includes behavioural modifications, pelvic floor physiotherapy, analgesics, pudendal nerve block (transacral block at S2-S4) and botox injections (in case of muscle spasms) [66-68]. In case of failed conservative treatment, surgical decompression via the transperineal, transgluteal 
Table 5. Treatment of painful bladder syndrome/ interstitial cystitis (pbs/ic)

\begin{tabular}{|c|c|c|c|c|c|c|}
\hline & $\begin{array}{l}\text { Pentosan } \\
\text { polysulfate }\end{array}$ & Antihistamines & Antidepressants & Neuroleptics & $\begin{array}{l}\text { Supplementary oral } \\
\text { therapy }\end{array}$ & Intravesical therapy \\
\hline $\begin{array}{l}\text { Mechanism } \\
\text { of action }\end{array}$ & $\begin{array}{l}\text { Re-establish } \\
\text { endothelial lining } \\
{[71]}\end{array}$ & Mast cell stabiliser & $\begin{array}{l}\text { Modify pain, improves } \\
\text { insomnia, anticholinergic } \\
\text { effect }\end{array}$ & $\begin{array}{l}\text { Decrease neurogenic } \\
\text { inflammation }\end{array}$ & $\begin{array}{l}\text { Decrease bladder } \\
\text { discomfort }\end{array}$ & $\begin{array}{l}\text { Decrease bladder discomfort, } \\
\text { control bladder spasm }\end{array}$ \\
\hline Example & - & $\begin{array}{l}\text { Hydroxyzine [72] } \\
\text { (sedating) } \\
\text { Cetirizine [73] } \\
\text { (non-sedating) }\end{array}$ & $\begin{array}{l}\text { Tricyclics - amitriptyline, } \\
\text { trazodone, doxepin, } \\
\text { nortriptyline } \\
\text { SSRI - paroxetine, } \\
\text { fluoxetine, citalopram, } \\
\text { venlafaxine, sertraline }\end{array}$ & $\begin{array}{l}\text { Gabapentin, phenytoin, } \\
\text { carbamazepine, } \\
\text { valproate }\end{array}$ & $\begin{array}{l}\text { Urinary analgesics, } \\
\text { antiseptics, alkalizers, e.g. } \\
\text { Phenazopyridine, Uromax, } \\
\text { Urised }\end{array}$ & $\begin{array}{l}\text { FDA approved: -Dimethyl } \\
\text { sulfoxide (DMSO); [74] } \\
\text {-Oxybutynin (5-10 mg } \\
\text { crushed and suspended in } \\
\text { 10cc of water); } \\
\text {-Pentosan polysulfate/ heparin } \\
\text { (daily) [75] } \\
\text { Non-FDA approved: } \\
\text {-Hyaluronidase [76] } \\
\text {-Bacillus Calmette-Guérin } \\
\text { (BCG) [77] }\end{array}$ \\
\hline Dose & $100-300 \mathrm{mg}$ & $25-75 \mathrm{mg}$ & $25-100 \mathrm{mg}$ & $100-800 \mathrm{mg}$ & & $50 \mathrm{cc}$ \\
\hline Route & Oral & Oral & Oral & Oral & & catheterisation \\
\hline Frequency & 3 times/day & Once at night & Once at night & 3 times/day & & Once/week for $>6$ weeks \\
\hline Side effects & $\begin{array}{l}\text { Headache, alopecia, } \\
\text { GI upset }\end{array}$ & $\begin{array}{l}\text { Visual disturbance, low } \\
\text { blood pressure, GI upset }\end{array}$ & Sympathomimetic effect & $\begin{array}{l}\text { Sedation, liver } \\
\text { impairment }\end{array}$ & & Bladder irritation \\
\hline Others & $\begin{array}{l}\text { Full effect may not be } \\
\text { seen for } 6-9 \text { months. } \\
\text { Compliance is } \\
\text { necessary as } \\
\text { benefit of therapy } \\
\text { is dependent on } \\
\text { length of time under } \\
\text { treatment. }\end{array}$ & $\begin{array}{l}\text { In spring and fall, when } \\
\text { many IC patients suffer } \\
\text { from seasonal allergies, an } \\
\text { additional } 10-25 \mathrm{mg} \text { every } \\
6 \text { hours may be required. }\end{array}$ & $\begin{array}{l}\text { Imipramine should be } \\
\text { avoided as this agent } \\
\text { exacerbates dysfunctional } \\
\text { voiding. }\end{array}$ & & - & $\begin{array}{l}\text { For patients who fail to } \\
\text { respond to oral therapy }\end{array}$ \\
\hline
\end{tabular}

GI: gastrointestinal

SSRI: Selective Serotonin Re-uptake Inhibitors

Dose, frequency, route stated in the table is of the underlined drug.
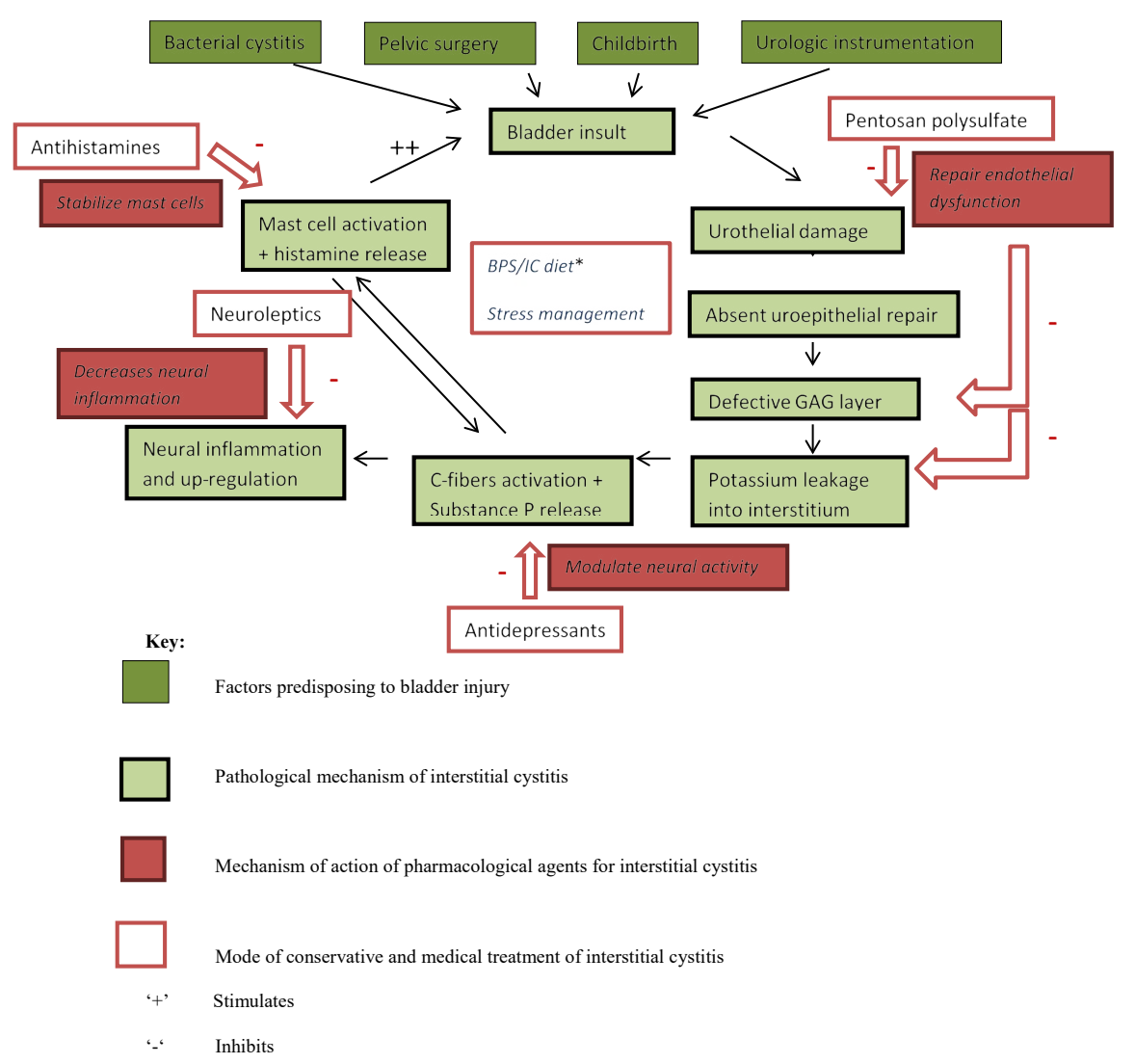

Figure 3. Multifactorial aetiology of Bladder pain syndrome/Interstitial cystitis (BPS/IC) and the role of multimodality therapy.

*Bladder pain Syndrome/Interstitial cystitis (BPS/IC) diet involves avoidance of coffee, tea, soda, alcohol, citrus juices, and cranberry juice, foods and beverages containing artificial sweeteners, hot peppers and spicy foods, which may exacerbate BPS/IC. 
Table 6. Nantes essential diagnostic criteria for pudendal nerve entrapment (all must be present)

Pain is expressed in the anatomical territory of the pudendal nerve (S 2, 3 and 4 - from the anus to the clitoris)

Pain is aggravated by sitting (Pain predominantly experienced on sitting)

The patient does not wake up during the night due to the absence of nocturnal pain

There is no objective sensory loss on clinical examination

There is positive response to anaesthetic block of the pudendal nerve.

(Pain relieved by diagnostic pudendal nerve block)

or transischiorectal approach), computed tomography-guided pulsedose radiofrequency of the pudendal nerve or spinal cord stimulation of the monus medullaris may be considered $[54,69,70]$.

\section{Conclusion}

When approaching a patient with chronic pelvic pain, it is important to consider interstitial cystitis, irritable bowel syndrome, pelvic floor dysfunction, pudendal neuralgia and endometriosis as differential diagnoses. CPP should be managed using a multidisciplinary and multimodal approach comprising medical, surgical and adjuvant therapies. Currently, clinical practice regarding CPP is still not sufficiently evidence-based. Given the significant emotional, physical and healthcare costs associated with CPP, there is a vital need for well-controlled randomized clinical trials to be performed. All physicians treating patients with pelvic pain have to be aware of all the potential causes of pelvic pain to ensure adequate and holistic approach to treatment. Addressing only the commonest cause will not lead to long lasting remission.

\section{Declaration of interest statement}

We have read the JMIG policy on declaration of interests and declared that we have no declarations of interest.

\section{Contributorship statement}

IIB planned the organisation, content and structure of the article. SS performed the literature review and drafted the article with crucial additions and edition from IIB. SS prepared the tables and figures and all authors participated in subsequent revisions and approved the final version.

\section{References}

1. Merskey H, Bogduk N (1994) Classification of chronic pain. (2 $2^{\text {nd }}$ edn) Seattle: IASP Press.

2. Daniels JP, Khan KS (2010) Chronic pelvic pain in women. BMJ 341: c4834. [Crossref]

3. Kothari S (2007) Neuromodulatory approaches to chronic pelvic pain and coccygodynia. Acta Neurochir Suppl 97: 365-371. [Crossref]

4. Howard FM (2011) The differential diagnosis of chronic pelvic pain in Chronic pelvic pain by Paolo Vercellini (editor). West Sussex: Wiley-Blackwell, pp: 7-28.

5. Zondervan KT, Yudkin PL, Vessey MP, Jenkinson CP, Dawes MG, et al. (2001) The community prevalence of chronic pelvic pain in women and associated illness behaviour. Br J Gen Pract 51: 541-547. [Crossref]

6. Mathias SD, Kupperman M, Liberman RF, Lipschutz RC, Steege JF (1996) Chronic pelvic pain: prevalence, health related quality of life and economic correlates. Obstet Gynecol 87: 838-841. [Crossref]

7. Chung MK, Chung RP, Gordon D (2005) Interstitial cystitis and endometriosis in patients with chronic pelvic pain: The "Evil Twins" syndrome. JSLS 9: 25-29. [Crossref]

8. Ortiz DD (2008) Chronic pelvic pain in women. Am Fam Physician 77: 1535-1542. [Crossref]

9. Giamberardino MA, Costantini R, Affaitati G, Fabrizio A, Lapenna D, et al. (2010) Viscero-visceral hyperalgesia: characterization in different clinical models. Pain 151: 307-322. [Crossref]
10. Raj PP (2000) Practical Management of Pain ( $3^{\text {rd }}$ edn) St. Louis, Mo: Mosby Inc, pp: $10-16$.

11. Raj PP (2000) Practical Management of Pain. ( ${ }^{\text {rd }}$ edn) St. Louis, Mo: Mosby Inc, pp 223-239.

12. Marcelissen T, Jacobs R, van Kerrebroeck P, de Wachter S (2011) Sacral neuromodulation as a treatment for chronic pelvic pain. J Urol 186: 387-393. [Crossref]

13. Janicki TI (2003) Chronic pelvic pain as a form of complex regional pain syndrome. Clin Obstet Gynecol 46: 797-803. [Crossref]

14. Cheong Y, William Stones R (2006) Chronic pelvic pain: aetiology and therapy. Best Pract Res Clin Obstet Gynaecol 20: 695-711. [Crossref]

15. McGowan L, Luker K, Creed F, Chew-Graham CA (2007) How do you explain a pain that can't be seen? the narratives of women with chronic pelvic pain and their disengagement with the diagnostic cycle. Br J Health Psychol 12: 261-274. [Crossref]

16. Price J, Farmer G, Harris J, Hope T, Kennedy S, et al. (2006) Attitudes of women with chronic pelvic pain to the gynaecological consultation: a qualitative study. BJOG 113 : 446-452. [Crossref]

17. Nickel JC, Shoskes D, Irvine-Bird K (2009) Clinical phenotyping of women with interstitial cystitis/painful bladder syndrome: a key to classification and potentially improved management. J Urol 182: 155-160. [Crossref]

18. Shoskes DA, Nickel JC, Kattan MW (2010) Phenotypically directed multimoda therapy for chronic prostatitis/chronic pelvic pain syndrome: a prospective study using UPOINT. Urology 75: 1249-1253. [Crossref]

19. Engeler DS, Baranowski AP, Dinis-Oliveira P, Elneil S, Hughes J, et al. (2013) The 2013 EAU guidelines on chronic pelvic pain: is management of chronic pelvic pain a habit, a philosophy, or a science? 10 years of development. Eur Urol 64: 431-439. [Crossref]

20. UPOINT System for the Clinical Phenotyping of Chronic Pelvic Pain - electronic calculator http://www.upointmd.com/begin.php. Assessed on 15/03/2015.

21. Learman LA (2014) What is new in chronic pelvic pain?: best articles from the past year. Obstet Gynecol 123: 1104-1105. [Crossref]

22. Neis KJ, Neis F (2009) Chronic pelvic pain: cause, diagnosis and therapy from a gynaecologist's and an endoscopist's point of view. Gynecol Endocrinol 25: 757-761. [Crossref]

23. Sharma D, Dahiya K, Duhan N, Bansal R (2011) Diagnostic laparoscopy in chronic pelvic pain. Arch Gynecol Obstet 283: 295-297.

24. Howard FM (1996) The role of laparoscopy in the evaluation of chronic pelvic pain pitfalls with a negative laparoscopy. J Am Assoc Gynecol Laparosc 4: 85-94. [Crossref]

25. Beard RW, Reginald PW, Wadsworth J (1988) Clinical features of women with chronic lower abdominal pain and pelvic congestion. Br J Obstet Gynaecol 95: 153161. [Crossref]

26. Haggerty CL, Peipert JF, Weitzen S, Hendrix SL, Holley RL, et al, (2005) Predictor of chronic pelvic pain in an urban population of women with symptoms and signs of pelvic inflammatory disease. Sex Transm Dis 32: 293-299.

27. ACOG Committee on Practice Bulletins-Gynecology (2000) ACOG practice bulletin Medical management of endometriosis. Number 11, December 1999 (replaces Technical Bulletin Number 184, September 1993). Clinical management guidelines for obstetrician-gynecologists. Int J Gynaecol Obstet 71: 183-196. [Crossref]

28. Memarzadeh S, Muse KN Jr, Fox MD (2003) Endometriosis. In: DeCherney AH, Nathan L, editors. Current Obstetric \& Gynecologic Diagnosis \& Treatment. ( $9^{\text {th }}$ edn) New York, NY: Lange Medical Books/McGraw-Hill pp: 767-775.

29. Schenken RS (1996) Treatment of human infertility: The special case of endometriosis In: Adashi EY, Rock JA, Rosenwaks Z, editors. Reproductive endocrinology, surgery, and technology. Vol. 2. Philadelphia: Lippincott-Raven, pp. 2121-2140.

30. Olive DL, Pritts EA (2001) Treatment of endometriosis. N Engl J Med 345: 266-275. [Crossref]

31. Sircus SI, Sant GR, Ucci AA Jr (1988) Bladder detrusor endometriosis mimicking interstitial cystitis. Urology 32: 339-342. [Crossref]

32. Practice Committee of the American Society for Reproductive Medicine (ARSM) (2006) Endometriosis and infertility. Fertil Steril 86: S156-S160. [Crossref]

33. Walter AJ, Hentz JG, Magtibay PM, Cornella JL, Magrina JF (2001) Endometriosis: correlation between histologic and visual findings at laparoscopy. Am J Obstet Gynecol 184: 1407-1413. [Crossref] 
34. Khan N, Carr BR (2004) Endometriosis, part 2: treatment options. Female Patient 29: 26-33.

35. Lentz GM, Bavendam T, Stenchever MA, Miller JL, Small-dridge J (2002) Hormonal manipulation in women with chronic, cyclic irritable bladder symptoms and pelvic pain. Am J Obstet Gynecol 186: 1268-1273. [Crossref]

36. Schwertner A, Conceicao Dos Santos CC, Costa GD, Deitos A, de Souza A, de Souza IC, et al. (2013) Efficacy of melatonin in the treatment of endometriosis: a phase II, randomised, double-blind, placebo-controlled trial. Pain 154: 874-881. [Crossref]

37. Bloski T, Pierson R (2008) Endometriosis and Chronic Pelvic Pain: Unraveling the Mystery Behind this Complex Condition. Nurs Womens Health 12: 382-395. [Crossref]

38. Vermeulen W, De Man JG, Pelckmans PA, De Winter BY (2014) Neuroanatomy of lower gastrointestinal pain disorders. World J Gastroenterol 20: 1005-1020. [Crossref]

39. Spiller R, Aziz Q, Creed F, Emmanuel A, Houghton L, et al. (2007) Guidelines on the irritable bowel syndrome: mechanisms and practical management. Gut 56: 1770-1798. [Crossref]

40. Longstreth GF, Thompson WG, Chey WD, Houghton LA, Mearin F, et al. (2006) Functional bowel disorders. Gastroenterology 130: 1480-1491. [Crossref]

41. NICE clinical guideline 61 (CG61) (2015) Clinical practice guideline Irritable bowel syndrome in adults: Diagnosis and management of irritable bowel syndrome in primary care.

42. Agrawal A, Whorwell PJ (2006) Irritable bowel syndrome: diagnosis and management. BMJ 332: 280-283. [Crossref]

43. Matheis A, Martens U, Kruse J, Enck P (2007) Irritable bowel syndrome and chronic pelvic pain: a singular or two different clinical syndrome? World J Gastroenterol 13: 3446-3455. [Crossref]

44. Choung RS, Herrick LM, Locke GR 3rd, Zinsmeister AR, Talley NJ (2010) Irritable bowel syndrome and chronic pelvic pain: a population-based study. $J$ Clin Gastroenterol 44: 696-701. [Crossref]

45. Longstreth GF (1997) Irritable bowel syndrome. Diagnosis in the managed care era. Dig Dis Sci 42: 1105-1111. [Crossref]

46. Berry SH, Stoto MA, Elliott W, Suttorp M, Bogart L, et al. (2009) Prevelance of interstitial cystitis/painful bladder syndrome in the United States. The Rand Interstitial Cystitis Epidemiology (RICE) study. Poster presented at the Annual Meeting of the American Urological Association. Chicago, IL.

47. Hanno P, Dmochowski R (2009) Status of international consensus on interstitia cystitis/bladder pain syndrome/painful bladder syndrome: 2008 snapshot. Neurourol Urodyn 28: 274-286. [Crossref]

48. Abrams P, Cardozo L, Fall M, Griffiths D, Rosier P, et al. (2002) Reports from the standardization subcommittee of the International Continence Society. Am J Obstet Gynecol 187: 116-126. [Crossref]

49. Comiter CV (2003) Sacral neuromodulation for the symptomatic treatment of refractory interstitial cystitis: a prospective study. J Urol 169: 1369-1373. [Crossref]

50. Van de Merwe JP, Nordling J, Bouchelouche P, Bouchelouche K, Cervigni M, et al. (2008) Diagnostic criteria, classification, and nomenclature for painful bladder syndrome/interstitial cystitis: an ESSIC proposal. Eur Urol 53: 60-67. [Crossref]

51. Oravisto KJ (1980) Interstitial cystitis as an autoimmune disease. A review. Eur Urol 6: 10-13. [Crossref]

52. Fariello JY, Whitmore K (2010) Sacral neuromodulation stimulation for IC/PBS, chronic pelvic pain, and sexual dysfunction. Int Urogynecol J 21: 1553-1558. [Crossref]

53. Keay S, Warren JW (1998) A hypothesis for the etiology of interstitial cystitis based upon inhibition of bladder epithelial repair. Med Hypotheses 51: 79-83. [Crossref]

54. Keay SK, Zhang C, Shoenfelt J, Erickson DR, Whitmore K, et al. (2001) Sensitivity and specificity of antiproliferative factor, heparin-binding epidermal growth factor-like growth factor and epidermal growth factor as unique markers for interstitial cystitis. Urology 57:9-14. [Crossref]

55. Sant GR, Theoharides TC (1994) The role of the mast cell in interstitial cystitis. Urol Clin North Am 21: 41-53. [Crossref]
56. Hohenfeller M, Nunes L, Schmidt RA, Lampel A, Thüroff JW, et al. Interstitial cystitis: increased sympathetic innervation and related neuropeptide synthesis. J Urol. 1992; 147:587-589. [Crossref]

57. Pang X, Marchand J, Sant GR, Kream RM, Theoharides TC (1995) Increased number of substance $\mathrm{P}$ positive nerve fibres in interstitial cystitis. Br J Urol 75: 744-750. [Crossref]

58. Nazif O, Teichman JM, Gebhart GF (2007) Neural upregulation in interstitial cystitis. Urology 69: 24-33. [Crossref]

59. Feler CA, Whitworth LA, Fernandez J (2003) Sacral neuromodulation for chronic pain conditions. Anesthesiol Clin North America 21: 785-795. [Crossref]

60. Keane DP, Abrams P and Bailey AJ (2005) Analysis of collagen status in premenopausal nulliparous women with genuine stress incontinence. Br J Obstet Gynaecol 104: 994997. [Crossref]

61. Neville CE, Fitzgerald CM, Mallinson T, Badillo S, Hynes C, et al. (2012) A preliminary report of musculoskeletal dysfunction in female chronic pelvic pain: a blinded study of examination findings. J Bodyw Mov Ther 16: 50-56. [Crossref]

62. Mishra GD, Cardozo L, Kuh D (2010) Menopausal transition and the risk of urinary incontinence: results from a British prospective cohort. BJU Int 106: 1170-1175. [Crossref]

63. Carmel M, Lebel M, Tu LM (2010) Pudendal nerve neuromodulation with neurophysiology guidance: a potential treatment option for refractory chronic pelviperineal pain. Int Urogynecol 21: 613-616. [Crossref]

64. Filler AG (2009) Diagnosis and treatment of pudendal nerve entrapment syndrome subtypes: imaging, injections and minimal access surgery. Neruosurg Focus 26: E9. [Crossref]

65. Labat JJ, Riant T, Robert R, Amarenco G, Lefaucheur JP, et al. (2008) Diagnostic Criteria for Pudendal Neuralgia by Pudendal Nerve Entrapment. Neurourol Urodyn 27: 306-310. [Crossref]

66. Rhame EE, Levery KA, Gharibo CG (2009) Successful treatment of refractory pudenda neuralgia with pulsed radiofrequency. Pain Physician 12: 633-638. [Crossref]

67. Cok OY, Eker HE, Cok T, Akin S, Aribogan A, et al. (2011) Transsacral S2-S4 nerve block for vaginal pain due to pudendal neuralgia. J Minim Invasive Gynecol 18: 401404. [Crossref]

68. Buffenori K, Rioult D, Damel O, Labat JJ, Riant T, et al. (2013) Spinal cord stimulation of the conus medularis for refractory pudendal neuralgia: a prospective study of 27 consecutive cases. Neurourol Urodyn 34: 177-182. [Crossref]

69. Masala S, Calabria E, Cuzzolino A, Raguso M, Morini M, et al. (2014) CT-guided percutaneous pulse-dose radiofrequency for pudendal neuralgia. Cardiovasc Intervent Radiol 37: 476-481. [Crossref]

70. Vancaillie T, Eggermont J, Armstrong G, Jarvis S, Liu J, et al. (2012) Response to pudendal nerve block in women with pudendal neuralgia. Pain Med 13: 596-603. [Crossref]

71. Parsons CL, Benson G, Childs SJ, Hanno P, Sant GR, et al. (1993) A quantitatively controlled method to prospectively study interstitial cystitis and demonstrate the efficacy of pentosan polysulfate. $J$ Urol 150: 845-848. [Crossref]

72. Theoharides TC, Sant GR (1997) Hydroyzine therapy for interstitial cystitis. Urology 49: 108-109. [Crossref]

73. Seshadri P, Emerson L, Morales A (1994) Cimetidine in the treatment of interstitial cystitis. Urology 44: 614-616. [Crossref]

74. Parkin J, Shea C, Sant GR (1997) Intravesical dimethyl sulfoxide (DMSO) for interstitial cystitis-a practical approach. Urology 49: 105-107. [Crossref]

75. Parsons CL, Housley T, Schmidt JD, Lebow D (1994) Treatment of interstitial cystitis with intravesical heparin. Br J Urol 73: 504-507. [Crossref]

76. Peters KM, Diokno AC, Steinert BW, Gonzalez JA (1998) The efficacy of intravesical bacillus Calmette-Guérin in the treatment of interstitial cystitis: long-term follow up. $J$ Urol 159: 1483-1486. [Crossref]

77. Morales A, Emerson L, Nickel JC (1997) Intravesical hyaluronic acid in the treatment of refractory interstitial cystitis. Urology 49: 111-113. [Crossref]

Copyright: @2018 Bolaji II. This is an open-access article distributed under the terms of the Creative Commons Attribution License, which permits unrestricted use, distribution, and reproduction in any medium, provided the original author and source are credited. 